\title{
Identification and Characterization of a Newly Isolated Shiga Toxin 2- Converting Phage from Shiga Toxin-Producing Escherichia coli
}

\author{
MASAHISA WATARAI, ${ }^{1,2}$ TOSHIO SATO,${ }^{1}$ MIDORI KOBAYASHI, ${ }^{1}$ TAKESHI SHIMIZU, ${ }^{1}$ \\ SHINJI YAMASAKI, ${ }^{1}$ TORU TOBE,${ }^{2}$ CHIHIRO SASAKAWA, ${ }^{2}$ \\ AND YOSHIFUMI TAKEDA ${ }^{1 *}$ \\ Research Institute, International Medical Center of Japan, Tokyo 162, ${ }^{1}$ and Department of \\ Bacteriology, Institute of Medical Science, University of Tokyo, Tokyo 108, ${ }^{2}$ Japan
}

Received 20 April 1998/Returned for modification 22 May 1998/Accepted 2 June 1998

\begin{abstract}
Shiga toxins 1 (Stx1) and 2 (Stx2) are encoded by toxin-converting bacteriophages of Stx-producing Escherichia coli (STEC), and so far two Stx1- and one Stx2-converting phages have been isolated from two STEC strains (A. D. O'Brien, J. W. Newlands, S. F. Miller, R. K. Holmes, H. W. Smith, and S. B. Formal, Science 226: 694-696, 1984). In this study, we isolated two Stx2-converting phages, designated Stx2Ф-I and Stx2Ф-II, from two clinical strains of STEC associated with the outbreaks in Japan in 1996 and found that Stx2Ф-I resembled 933W, the previously reported Stx2-converting phage, in its infective properties for $E$. coli K-12 strain C600

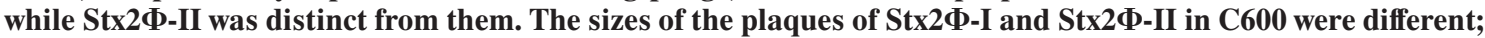
the former was larger than the latter. The restriction maps of Stx2 $\Phi$-I and Stx2 $\Phi$-II were not identical; rather,

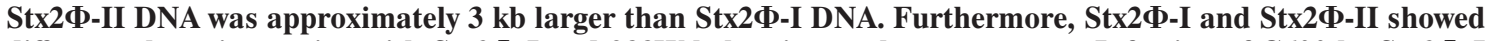
different phage immunity, with Stx2 $\Phi$-I and $933 \mathrm{~W}$ belonging to the same group. Infection of C600 by Stx2Ф-I or $933 \mathrm{~W}$ was affected by environmental osmolarity differently from that by Stx2Ф-II. When C600 was grown under conditions of high osmolarity, the infectivity of Stx2 $\Phi-I$ and $933 \mathrm{~W}$ was greatly decreased compared with that of Stx2Ф-II. Examination of the plating efficiency of the three phages for the defined mutations in C600 revealed that the efficiency of Stx2 $\Phi$-I and $933 \mathrm{~W}$ for the $\mathrm{fad} \mathrm{L}$ mutant decreased to less than $10^{-7}$ compared with that for $\mathrm{C600}$ whereas the efficiency of Stx2Ф-II decreased to $0.1 \%$ of that for C600. In contrast, while the plating efficiency of Stx2 $\Phi$-II for the lamB mutant decreased to a low level $(0.05 \%$ of that for C600), the efficiencies of Stx2 $\Phi-I$ and $933 \mathrm{~W}$ were not changed. This was confirmed by the phage neutralization experiments with isolated outer membrane fractions from $\mathrm{C600}$, fadL mutant, or lamB mutant or the purified His $_{6}$-tagged FadL and LamB proteins. Based on the data, we concluded that FadL acts as the receptor for Stx2థ-I and

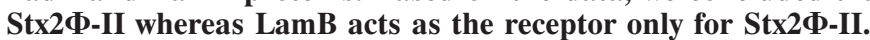

Shiga toxin-producing Escherichia coli (STEC) strains are associated with diarrhea, hemorrhagic colitis, and the hemolytic-uremic syndrome (HUS) in humans. Serotype O157:H7 constitutes the main STEC causative serotype, but other serotypes such as O26:H11 are also involved (24). The frequency with which STEC infections are being reported continues to increase, probably reflecting both a greater interest in this pathogen and a real increase in its incidence and geographic spread (10). In Japan, an epidemic STEC O157:H7 infection started with a large outbreak in primary schools in Okayama in 1996, which involved 468 patients, 2 of whom developed HUS and died (52). This was followed by a large outbreak of STEC O157:H7 infection in primary schools in Osaka in 1996, affecting more than 6,000 children (52).

STEC isolated from patients with hemorrhagic colitis produces two immunologically distinct toxins that are cytotoxic to Vero cells $(47,49)$. One of the two Vero toxins is physicochemically, biologically, and immunologically identical to Shiga toxin from Shigella dysenteriae type 1 (32) and is known as Shiga toxin 1 (Stx1), while the other is immunologically unrelated to Shiga toxin $(49,58)$ and is known as Shiga toxin 2 (Stx2). Both Stx1 and Stx2 have been purified and their physicochemical and biological properties have been reported $(32,58)$. It has been proposed that the E. coli $\mathrm{O} 157: \mathrm{H}^{-}$strain E32511 pro-

\footnotetext{
* Corresponding author. Mailing address: Research Institute, International Medical Center of Japan, 1-21-1, Toyama, Shinjuku-ku, Tokyo 162, Japan. Phone: 81-3-5273-6844. Fax: 81-3-3202-7364. E-mail: resedr@imcj.go.jp.
}

duces yet another distinct toxin resembling the Stx2 family (14). Two variants of Stx2 have been well characterized $(9,54)$. The variants, designated SLT-IIv (Stx2e) and SLT-IIva, are cytotoxic for Vero and HeLa cells. SLT-IIv (Stx2e) is the causative agent of edema disease in pigs $(25,54)$, while SLT-IIva has been associated with diarrhea in a human infant (21).

Several investigators have reported that production of Stx1 and Stx 2 in E. coli is conferred by toxin-converting bacteriophages $(33,47-49)$. The Stx1 encoded on the phages was first demonstrated in E. coli O26:H11 strain H19 (47, 48). Strain H19 was lysogenized by two Stx-converting phages, designated H19A and H19B, which possess different host ranges. Phage H19B is related to coliphage lambda and carries the stx1 operon far from the attachment site, indicating that it became bacteriophage associated in the distant past (19). O'Brien et al. reported that another STEC O157:H7 strain, 933, was lysogenized with two Stx-converting phages, designated 933J and 933W; phage 933J was indistinguishable from the Stxconverting phage H19A of E. coli H19 (33). They also reported that E. coli 933 makes both Stx1 and Stx2 and that Stx1 is encoded by phage $933 \mathrm{~J}$ while Stx 2 is encoded by phage $933 \mathrm{~W}$ (49). Subsequently, we also reported that STEC O157:H7 strain 83-1386 or J-2 was lysogenized with Stx1- or Stx2-converting phage and that the phages were similar to those of H19B and 933W, respectively $(23,59)$. In summary, two Stx1converting phages, represented by $\mathrm{H} 19 \mathrm{~B}$ and $933 \mathrm{~J}$, and one Stx2-converting phage, represented by $933 \mathrm{~W}$, have been reported in the literature to date (35).

Interestingly, it has been reported that none of the Stx- 
TABLE 1. Bacterial strains and plasmids used in this study

\begin{tabular}{|c|c|c|}
\hline $\begin{array}{l}\text { Strain or } \\
\text { plasmid }\end{array}$ & $\begin{array}{l}\text { Genotype and relevant } \\
\text { characteristic(s) }\end{array}$ & $\begin{array}{l}\text { Source or } \\
\text { reference }\end{array}$ \\
\hline \multicolumn{3}{|l|}{ Strains } \\
\hline C600 & $\begin{array}{l}\text { supE44 hsdR thi-1 thr-1 leuB6 lacY1 } \\
\text { tonA21 }\end{array}$ & 41 \\
\hline XL1-Blue & Host strain for cloning & Strategene \\
\hline Okayama O-27 & Clinical isolate of E. coli $\mathrm{O} 157: \mathrm{H} 7$ & T. Takeda \\
\hline Morioka V526 & Clinical isolate of E. coli $\mathrm{O} 157: \mathrm{H} 7$ & T. Takeda \\
\hline Sakai V443 & Clinical isolate of E. coli $\mathrm{O} 157: \mathrm{H} 7$ & T. Takeda \\
\hline Osaka V743 & Clinical isolate of E. coli $\mathrm{O} 157: \mathrm{H} 7$ & T. Takeda \\
\hline Yokohama 97.4-C & Clinical isolate of $E$. coli $\mathrm{O} 157: \mathrm{H} 7$ & T. Takeda \\
\hline C600(Stx2Ф-I) & C600 lysogenized with Stx2Ф-I; Stx2 $2^{+}$ & This study \\
\hline C600(Stx2Ф-II) & C600 lysogenized with Stx2Ф-II; Stx $2^{+}$ & This study \\
\hline C600(933W) & $\begin{array}{l}\text { C600 lysogenized with phage } 933 \mathrm{~W} \text {; } \\
\text { Stx } 2^{+}\end{array}$ & A. D. O’Brien \\
\hline RAM191 & $\Delta o m p C 178$ zei-198::Tn10 & 28 \\
\hline RK4786 & ompF::Tn5 & 15 \\
\hline RS3338 & fadL71::Tn10 fadR & 37 \\
\hline GS20 & $\operatorname{lamB20::\operatorname {Tn}5}$ & T. J. Silhavy \\
\hline MW47 & $\begin{array}{l}\text { C600 lamB20::Tn5 transductant of } \\
\text { GS20 donor }\end{array}$ & This study \\
\hline MW72 & $\begin{array}{l}\text { C600 fadL71::Tn10 transductant } \\
\text { of RS3338 donor }\end{array}$ & This study \\
\hline MW78 & $\begin{array}{l}\text { MW72 lamB20::Tn5 transductant of } \\
\text { GS20 donor }\end{array}$ & This study \\
\hline \multicolumn{3}{|l|}{ Plasmids } \\
\hline pUC119 & Cloning vector & Takara \\
\hline pMAW301 & $\begin{array}{l}\text { Vector pUC119 cloned C600 lamB } \\
\text { gene }\end{array}$ & This study \\
\hline pMAW302 & $\begin{array}{l}\text { Vector pUC119 cloned C600 fadL } \\
\text { gene }\end{array}$ & This study \\
\hline pSU18 & pACYC184-derived cloning vector & 3 \\
\hline pMAW320 & Vector pSU18 cloned C600 fadL gene & This study \\
\hline pQE30 & $\begin{array}{l}\text { Vector for } \mathrm{His}_{6} \text {-tagged recombinant } \\
\text { protein }\end{array}$ & Qiagen \\
\hline pMAW311 & Vector pQE30 cloned C600 fadL gene & This study \\
\hline pMAW312 & Vector pQE30 cloned C600 lamB gene & This study \\
\hline
\end{tabular}

producing $S$. dysenteriae type I strains or Stx 2 variant-producing $E$. coli strains possess the toxin-converting phages. In fact, DNA hybridization analysis with probes specific for toxin-converting phage DNA revealed that several STEC and edema disease-causing strains, but not Shigella strains, possessed H19Aor $933 \mathrm{~W}$-related phage sequences, although the mechanism of infection of the Stx-converting phages in E. coli strains remains obscure (31). Therefore, these studies led us to investigate whether the production of Stx1 or Stx2 from STEC strains isolated from the outbreaks in Japan are associated with Stx-converting phages.

In this study, we isolated two distinct Stx2-converting phages, designated Stx $2 \Phi-I$ and Stx2 $\Phi-I I$, from clinical strains of STEC associated with the outbreak in Japan in 1996. Examination of the phage plaque sizes, the restriction endonuclease maps, the specificity of lysogenic immunity, the osmotic regulation of infection, and the receptors indicated that Stx2 $\Phi-I$ and Stx2 $\Phi-I I$ are different in their infective properties. The possibility of diverse host $E$. coli strains acquiring Stx2-converting phages and its implications are discussed.

\section{MATERIALS AND METHODS}

Bacterial strains, growth media, and plasmid construction. The bacterial strains and plasmids used in this study are listed in Table 1 . The growth media used were Luria-Bertani (LB) broth prepared with half the usual amount of $\mathrm{NaCl}$ and supplemented with $2.5 \mathrm{mM} \mathrm{CaCl}_{2}$. When necessary, ampicillin, kanamycin, tetracycline, or chloramphenicol was added at $100,30,50$, or $50 \mu \mathrm{g} / \mathrm{ml}$, respectively. pMAW302 and pMAW320 were constructed by ligating an 1,800-bp EcoRI fragment encompassing the nucleotides from position 303 upstream of the $5^{\prime}$ end of fadL to position 153 downstream from the $3^{\prime}$ end (4), which was amplified by PCR with the primers 5'-GAATTCCGGAAAGTGCTGCTCCAG TTGTTAA-3' and 5'-GAATTCCTGTGGATACCGCTTATTGATTTGA-3'. Both primers contained an EcoRI site. pMAW301 was constructed by ligating a 1,600-bp EcoRI fragment encompassing the nucleotides from position 100 upstream of the $5^{\prime}$ end of $\operatorname{lamB}$ to position 160 downstream from the $3^{\prime}$ end (5), which was amplified by PCR with the primers 5'-GAATTCTCGACTGCAT AAGGAGCCGGGCGTT-3' and 5'-GAATTCTTCAGATAATGACAACCTG TTTTTTA-3'. Both primers contained an EcoRI site.

Genetic procedures. Transformation was performed as described by Dagert and Erlich (6). Generalized transduction with bacteriophage P1 was carried out as described by Miller (27).

Preparation of Stx2-converting phages from STEC strains. The method for the preparation of Stx2-converting phages from STEC strains has been described previously $(23,59)$. Each STEC strain was grown at $37^{\circ} \mathrm{C}$ for $2 \mathrm{~h}$ in $\mathrm{LB}$ broth supplemented with $2.5 \mathrm{mM} \mathrm{CaCl} 2$. The cells were harvested by centrifugation, suspended in saline, and irradiated with UV light. The irradiated bacteria were inoculated into the same medium and incubated at $37^{\circ} \mathrm{C}$ for $2 \mathrm{~h}$. A few drops of chloroform was added to the culture, and the supernatant obtained by centrifugation was sterilized by being passed through a Millipore (Bedford, Mass.) filter membrane (pore size, $0.45 \mu \mathrm{m}$ ). The sterilized supernatant was mixed with a fresh culture of E. coli C600, added to LB soft agar, and poured onto an LB hard-agar plate. Lysogenized bacteria were isolated from each plaque formed on the plate, and the stx 2 gene of each lysogenized strain was determined by colony hybridization with an $s t x 2$ gene probe (59).

Colony screening by stx gene probe hybridization. Lysogenized bacteria were cultured on nylon membranes (GeneScreen hybridization transfer membranes [NEN Research Products, Boston, Mass.]) placed over LB agar plates. The plates were incubated at $37^{\circ} \mathrm{C}$ until bacterial colonies reached approximately $1 \mathrm{~mm}$ in diameter. The bacterial colonies on the nylon membrane were lysed, the chromosomal DNA was denatured by published procedures (8), and the nylon membranes were analyzed by Southern hybridization with digoxigenin-labeled stx 1 or $s t x 2$ gene probes, which contained an intact $s t x 1$ or $s t x 2$ gene, respectively (23, 59). Southern hybridization was performed by following the instruction manual provided with the DNA labeling and detection kit (Boehringer, Mannheim, Germany). Among the lysogenized strains screened, lysogenized E. coli C600

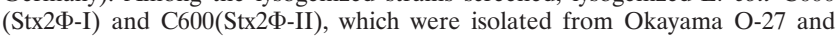
Morioka V526, respectively, were used to isolate Stx2Ф-I and Stx2Ф-II.

ELISA. A previously developed sensitive enzyme-linked immunosorbent assay (ELISA) (36) that can detect as little $50 \mathrm{pg}$ of Stx 2 per ml was used for the toxin assay. Filter-sterilized culture supernatants and bacterial lysates obtained by sonication were tested by the ELISA. Polystyrene beads coated with anti-Stx2 were used as the solid phase. Fab' of anti-Stx 2 conjugated with horseradish peroxidase by the maleimide method (20) was used as the second antibody, and the substrate was tetramethylbenzidine.

Assay for cytotoxicity. Assay for cytotoxicity to Vero cells was performed as described previously (32). Briefly, Vero cells were grown in Eagle's minimal essential medium supplemented with $2 \%$ fetal calf serum, $0.4 \%$ glucose, $0.15 \%$ sodium bicarbonate, and $0.003 \%$ phenol red. Cytotoxicity was assayed in wells of a Falcon microtiter plate (Becton Dickinson, Franklin Lakes, N.J.). About $10^{4}$ cells in $0.15 \mathrm{ml}$ of growth medium were seeded into each well. Filter-sterilized culture supernatants and bacterial lysates obtained by sonication were tested for cytotoxicity. Test samples $(0.02 \mathrm{ml})$ were added to each well and incubated under $5 \% \mathrm{CO}_{2}$ in air at $37^{\circ} \mathrm{C}$. The cells were observed microscopically for 7 days. The cytotoxic titers were determined by using 10 -fold serial dilutions; the highest toxin dilution that caused lysis of $50 \%$ of the cell monolayer was taken as the titer of each toxin.

Restriction mapping and cloning. Restriction endonucleases were purchased from Takara Shuzo (Tokyo, Japan), and digestions were performed by following the instructions of the manufacturer. Phage lambda DNA digested with HindIII or a 1-kb DNA ladder (GIBCO BRL, Rockville, Md.) was used as a molecular weight standard. The phage DNA was digested with BamHI or XhoI. These digested fragments were ligated with BamHI or XhoI-digested pBluescript (Stratagene, La Jolla, Calif.) and were transformed into E. coli XLI-Blue. Finally, all digested fragments were cloned. Restriction mapping was performed by a variety of methods, including double digestion, digestion of isolated fragments, Southern hybridization, and partial sequencing.

DNA sequencing. Nucleotide sequencing was carried out by the chain termination technique of Sanger et al. (44) with the dye terminator kit (Applied Biosystems Inc., Norwalk, Conn.). The universal T3 and T7 primers and synthetic oligonucleotide primers were used for sequencing in a walking strategy. Oligonucleotide primers for sequencing were synthesized on an Oligo1000M DNA synthesizer (Beckman, Palo Alto, Calif.) and purified by reverse-phase highpressure liquid chromatography (Waters, Milford, Mass.). The DNA sequence was obtained with an ABI 377 automated sequencer (Applied Biosystems Inc.).

Phage sensitivity testing and phage neutralization. Phage sensitivity was quantitated by placing the test culture, which was incubated with 10 -fold-serially diluted portions of the phage, in an overlay on LB agar plates, and the plates were incubated at $37^{\circ} \mathrm{C}$ for $18 \mathrm{~h}$. The PFU were calculated by counting the plaque numbers (41)

(i) Infection of Stx2-converting phage under high-osmolarity conditions. Strain C600 was cultured in LB broth samples supplemented with various concentrations of $\mathrm{NaCl}$ or sucrose, which were used as high-osmolarity media. The 


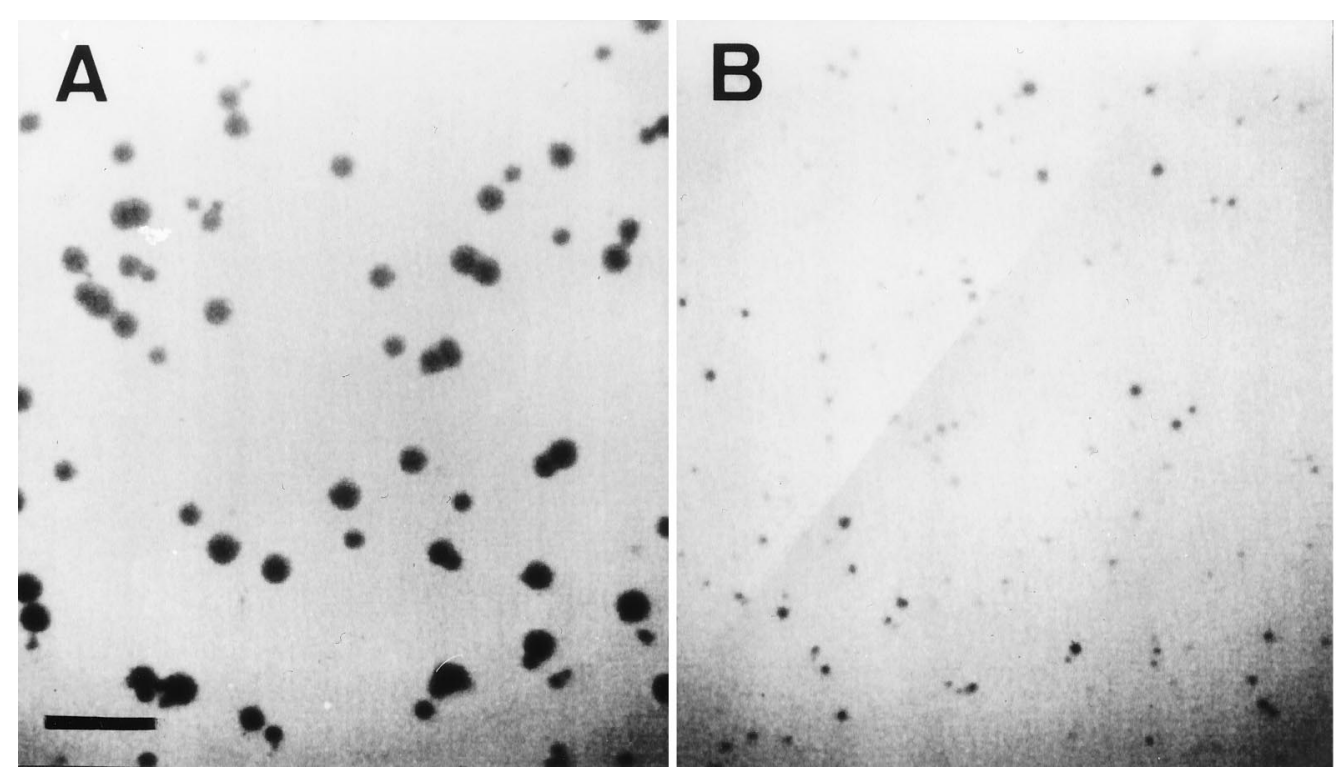

FIG. 1. Forms of plaques on a lawn of E. coli C600 infected with Stx $2 \Phi-I$ and Stx $2 \Phi-I I$. The C600 culture $\left(5 \times 10^{7}\right.$ cells $)$ was incubated with $5 \times 10^{3}$ PFU of Stx $2 \Phi-$ I (A) or Stx $2 \Phi-I I(B)$ at $37^{\circ} \mathrm{C}$ for $60 \mathrm{~min}$. These mixtures were plated to determine the form of the phages and incubated at $37^{\circ} \mathrm{C}$ for $18 \mathrm{~h}$. Bar, $10 \mathrm{~mm}$.

bacterial culture $\left(5 \times 10^{7}\right.$ cells) was incubated with $5 \times 10^{3} \mathrm{PFU}$ of Stx2-converting phage in a volume of $0.2 \mathrm{ml}$. After incubation at $37^{\circ} \mathrm{C}$ for $60 \mathrm{~min}$, the samples were plated to determine the infecting phage.

(ii) Stx2-converting phage neutralization by the outer membrane fraction. Outer membrane were prepared from $50 \mathrm{ml}$ of cells grown to an optical density at $600 \mathrm{~nm}$ of $1.0 \mathrm{in} \mathrm{LB}$ broth essentially by the method of Manning et al. (26). The insoluble fraction obtained after extraction of whole-cell envelopes with $2 \%$ Triton X-100 and $5 \mathrm{mM} \mathrm{MgCl}_{2}$ was called the outer membrane fraction, and it was suspended in distilled water and stored at $-20^{\circ} \mathrm{C}$. The outer membrane fraction $(100 \mu \mathrm{g} / \mathrm{ml})$ was incubated with $5 \times 10^{3} \mathrm{PFU}$ of Stx2-converting phage in a volume of $1 \mathrm{ml}$. After incubation at $37^{\circ} \mathrm{C}$ for $60 \mathrm{~min}, 0.2-\mathrm{ml}$ samples were plated with strain C600 to determine the plaque number of surviving phage.

(iii) Stx2-converting phage neutralization by $\mathrm{His}_{6}$-tagged FadL or LamB protein. A fusion protein purification was performed as described previously (53). A fusion protein of FadL and LamB tagged with six histidine residues at the $\mathrm{N}$ terminus was constructed by using the QIAexpress system with pQE-30 plasmic (Qiagen, Valencia, Calif.). The FadL-LamB fusion protein purified by Ni-nitrilotriacetic acid chromatography (Qiagen) was used for the Stx2-converting phage neutralization experiments described in Fig. 5. Purified fusion protein was incubated with $5 \times 10^{3} \mathrm{PFU}$ of Stx2-converting phage in a volume of $1 \mathrm{ml}$. After incubation at $37^{\circ} \mathrm{C}$ for $60 \mathrm{~min}, 0.2-\mathrm{ml}$ samples were plated with strain C600 to determine the plaque number of surviving phage.

\section{RESULTS}

Isolation of Stx2-converting phages from STEC strains. Five STEC O157:H7 strains associated with different outbreaks in Japan in 1996 (Table 1) were used to search for Stx2-converting phages. Each of the representative strains used produced large amounts of Stx1 and Stx2 (data not shown). In a typical experiment, approximately 500 plaques formed on a plate seeded with C600 by UV induction from a STEC strain such as Morioka V526. To isolate Stx1- or Stx2-converting phages, we excised some of the plaques, purified them on LB agar plates, and examined them for the presence of stx 1 or stx 2 genes by colony hybridization with stx 1 or stx 2 gene probes (see Materials and Methods). The yield of plaques that gave rise to stx1and stx2-positive clones obtained from Okayama O-27 or Yokohama $97.4-\mathrm{C}$ was 2 to $10 \%$, and the yield of plaques from Morioka V526 was 5 to $10 \%$. Interestingly, the morphology of the plaques which gave rise to the stx1-positive clones was uniform, while those which gave the stx2-positive clones included plaques with diameters of 1 and $3 \mathrm{~mm}$ (Fig. 1). We therefore designated the two representative phages which hybridized with the stx2 probe Stx2Ф-I (3-mm plaque) and Stx2Ф-II (1$\mathrm{mm}$ plaque), and these were derived from Okayama O-27 and Morioka V526, respectively (Fig. 1).

Characterization of Stx2-converting phages. To assess the

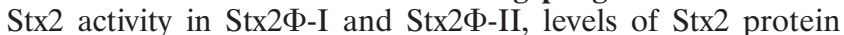
present in the whole bacterial lysates or culture supernatants of C600 lysogenized with Stx2Ф-I or Stx2Ф-II were investigated by the polystyrene bead ELISA with anti-Stx 2 antibody or by the cytotoxicity assay using Vero cells. As shown in Table 2, similar amounts of Stx2 were expressed from C600(Stx2Ф-I) and C600(Stx2 $\Phi-\mathrm{II})$, although the level of intracellular Stx2 production was half of the level in Okayama O-27 or Morioka V526 cells. Although some Stx 2 was secreted from the two C600 lysogens into the culture supernatants, the level of each was $1 / 10$ of that secreted from the parental O157:H7 strains. This result was also reproducible in the Vero cell cytotoxicity assay; however, the levels of Stx2 secreted into the culture supernatants of $\mathrm{C} 600(\mathrm{Stx} 2 \Phi-\mathrm{I})$ and C600(Stx2Ф-II) were further reduced compared with those of Okayama O-27 and Morioka V526 (Table 2). These data suggest that Stx2Ф-I and Stx2Ф-II encode Stx2-associated toxin and that in Okayama O-27 or Morioka V526, the Stx2 protein can be secreted into

TABLE 2. Stx 2 production and cytotoxicity of original and Stx2-converting phage-lysogenized strains

\begin{tabular}{|c|c|c|c|c|}
\hline \multirow{2}{*}{ Strain } & \multicolumn{2}{|c|}{$\begin{array}{l}\text { Stx } 2 \text { production } \\
\text { (ng/ml) by: }\end{array}$} & \multicolumn{2}{|c|}{$\begin{array}{l}\mathrm{CD}_{50}^{c} \text { (Vero cell } \\
\text { assay) for: }\end{array}$} \\
\hline & $\mathrm{Cell}^{a}$ & $\operatorname{Sup}^{b}$ & Cell & Sup \\
\hline Okayama O-27 & 62 & 122 & $10^{5}$ & $10^{7}$ \\
\hline Morioka V526 & 74 & 120 & $10^{6}$ & $10^{7}$ \\
\hline C600 & $\mathrm{ND}^{d}$ & ND & $<10$ & $<10$ \\
\hline C600(Stx2Ф-I) & 32 & 12 & $10^{4}$ & $10^{3}$ \\
\hline C600(Stx2Ф-II) & 28 & 10 & $10^{4}$ & $10^{3}$ \\
\hline
\end{tabular}

${ }^{a}$ Supernatant obtained by centrifugation of cell sonicate of an overnight culture.

${ }^{b}$ Supernatant of an overnight culture.

${ }^{c} \mathrm{CD}_{50}$, highest toxin dilution that caused lysis of $50 \%$ of the cell monolayer.

${ }^{d} \mathrm{ND}$, not detectable. 
TABLE 3. Capacity of Stx2-converting phages to form plaques on various $E$. coli hosts

\begin{tabular}{|c|c|c|c|}
\hline \multirow{2}{*}{ Strain } & \multicolumn{3}{|c|}{ Phage titer } \\
\hline & Stx2Ф-I & Stx2Ф-II & $933 \mathrm{~W}$ \\
\hline C600 & $2.4 \times 10^{7}$ & $2.6 \times 10^{7}$ & $3.9 \times 10^{7}$ \\
\hline C600(Stx2Ф-I) & $\mathrm{ND}^{a}$ & $2.0 \times 10^{7}$ & ND \\
\hline C600(Stx2Ф-II) & $2.5 \times 10^{7}$ & ND & $3.3 \times 10^{7}$ \\
\hline C600(933W) & ND & $2.5 \times 10^{7}$ & ND \\
\hline
\end{tabular}

${ }^{a} \mathrm{ND}$, not detectable.

the culture supernatants more efficiently than in the respective lysogenized C600 strains.

Relationship of Stx2-converting phages to $933 \mathrm{~W}$. To assess the relationship between Stx $2 \Phi-I$ or Stx $2 \Phi-I I$ and $933 \mathrm{~W}$, which is the sole Stx2-converting phage known that has been isolated from O157:H7 (933 strain) (33), we examined the three phages for their lysogenic immunity. As shown in Table 3, Stx2 $\Phi$-I and Stx2Ф-II showed no immunity to each other whereas Stx2Ф-I, but not Stx2 $\Phi$-II, showed immunity to $933 \mathrm{~W}$, suggesting that Stx $2 \Phi-I$ is closely related to $933 \mathrm{~W}$ but not to Stx $2 \Phi-I I$.

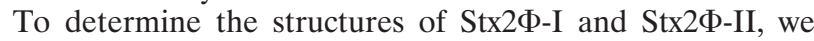
constructed restriction maps of the phage DNA including the location of the two stx 2 genes as described in Materials and Methods. As shown in Fig. 2, although the restriction maps are similar, the full length of Stx2 $\Phi$-II was $3 \mathrm{~kb}$ longer than Stx2 $\Phi$ $\mathrm{I}$, which resulted mostly from the differences of each of the BamHI-XhoI fragments containing the stx 2 gene. In this study, we sequenced the two stx2 genes in Stx2Ф-I and Stx2Ф-II and found that the two stx 2 sequences were identical to each other and that they were also identical to the stx 2 gene from $933 \mathrm{~W}$ $(11,21,22,54)$. The open reading frames containing the stx 2 gene of Stx2 $\Phi-I$ and Stx2 $\Phi-I I$ were located downstream of $p$ gene of phage $\lambda$, as is the case for the stx 2 gene in $933 \mathrm{~W}(7,45)$.

Effect of osmolarity on phage infection. To further characterize Stx2 $\Phi$-II, we examined whether infection of $E$. coli $\mathrm{K}-12$ by the phages was affected by changes in the osmolarity of LB broth, since the infection efficiency of Stx-converting phages has been shown to be affected by the osmolarity of the culture medium for growing the indicator E. coli strain (33). C600 was grown in $\mathrm{LB}$ broth containing various concentrations of $\mathrm{NaCl}$ (0 to $0.6 \mathrm{M})$ or sucrose $(0$ to $30 \%)$, the bacteria were infected with $5 \times 10^{3}$ PFU of Stx2-converting phages for $1 \mathrm{~h}$ in the media, and the numbers of infected phages were measured as described in Materials and Methods. As shown in Fig. 3, the infection efficiency of Stx2Ф-I, Stx2Ф-II, or 933W decreased as the concentration of $\mathrm{NaCl}$ (Fig. 3A) or sucrose (Fig. 3B) increased. Therefore, the effects of an increase in the osmolarity on the infection efficiency of Stx $2 \Phi-I$ and $933 \mathrm{~W}$ are similar and are greater than the effects on the infection efficiency of Stx2 $\Phi$ II.

Involvement of outer membrane-associated proteins of $\boldsymbol{E}$. coli in Stx2Ф-II infection. Stx-converting phages are lambdoid phages $(7,18,19,45)$, and therefore the involvement of the $\operatorname{lam} B$ gene (coding for the LamB protein) in the infection of $\mathrm{C} 600$ by Stx $2 \Phi-$ II was checked. The lamB20::Tn 5 mutation of GS20 was introduced by P1 phages into C600, and one of the lamB20::Tn5 transductants, designated MW47, was examined for phage sensitivity. Although MW47 ( $\operatorname{lamB})$ was sensitive to Stx2Ф-I and $933 \mathrm{~W}$, its sensitivity to Stx2Ф-II was greatly diminished (to $0.1 \%$ of that to Stx $2 \Phi-I$ and $933 \mathrm{~W}$ ) (Table 4). The reduced efficiency of Stx2 $\Phi$-II to infect MW47 (lamB) was restored upon introduction of pMAW301 (the cloned lamB gene in pUC119), suggesting that the LamB protein is important for Stx2 $\Phi$-II infection of C600.

We reasoned that the expression of the phage receptor could be osmolarity regulated, since the infection of C600 by Stx $2 \Phi-$ I and $933 \mathrm{~W}$ was greatly affected by changing the osmolarity of the medium used to grow C600. Since the outer membrane porin proteins such as $\mathrm{OmpF}$ and $\mathrm{OmpC}$ are known to be the receptors of phage $\mathrm{T} 2$ and $\mathrm{T} 4$, respectively $(13,16,30)$ and FadL is known to be the receptor of phage T2 (31), the effects of defined mutations of ompC, ompF, or fadL in E. coli on infection of the three converting phages were examined. Examination of the sensitivity of RAM191 $\Delta$ ompC178 zei-198:: Tn10 (28) and RK4786 ompF::Tn5 (15) mutants to the three Stx2-converting phages showed no significant difference among the phages, suggesting that $\mathrm{OmpC}$ and $\mathrm{OmpF}$ were not involved in phage infection. In contrast, when a fadL mutation was introduced into C600(MW72), the bacteria become resistant to Stx $2 \Phi-I$ and $933 \mathrm{~W}$ and partly resistant to Stx2Ф-II (Table 4). The introduction of pMAW302 (a cloned fadL gene) into MW72 ( $\mathrm{fadL})$ restored its sensitivity to Stx2Ф-I and 933W, clearly indicating that the FadL protein plays a crucial role in the infection of $E$. coli by Stx $2 \Phi-\mathrm{I}$ and $933 \mathrm{~W}$.

To further investigate the contribution of FadL and LamB proteins in the infection of $E$. coli by Stx2-converting phage, a fadL-lamB double mutation was constructed in C600 (MW78 [fadL $\operatorname{lamB}]$ ) and examined for the extent of resistance to Stx2Ф-II. As shown in Table 4, the sensitivity of MW78 ( $f a d L$ lamB) to Stx2 $\Phi$-II disappeared, but it was almost completely

\begin{tabular}{ccccccc}
0 & 10 & 20 & 30 & 40 & 50 & $60(\mathrm{~Kb})$ \\
& 1 & 1 & 1 & 1 & 1 & \\
\hline
\end{tabular}
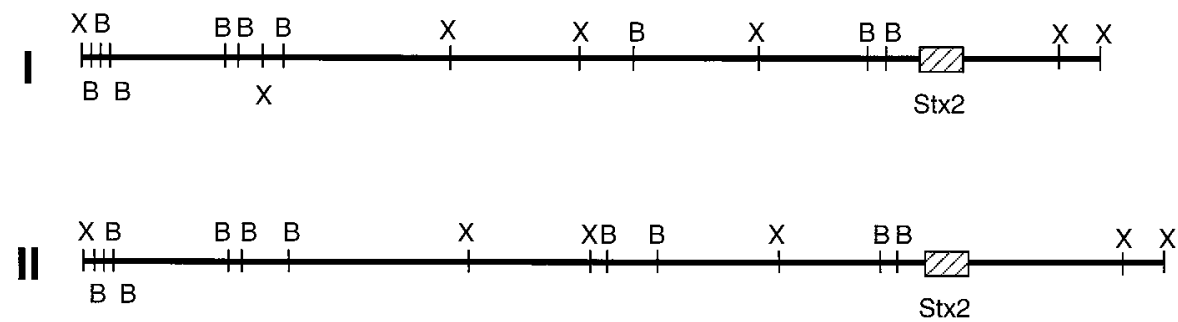

FIG. 2. Restriction endonuclease maps of Stx2 $2-\mathrm{I}$ (I) and Stx2Ф-II (II). Areas of the stx2 gene are indicated by solid boxes. Abbreviations: B, BamHI; X, XhoI. 

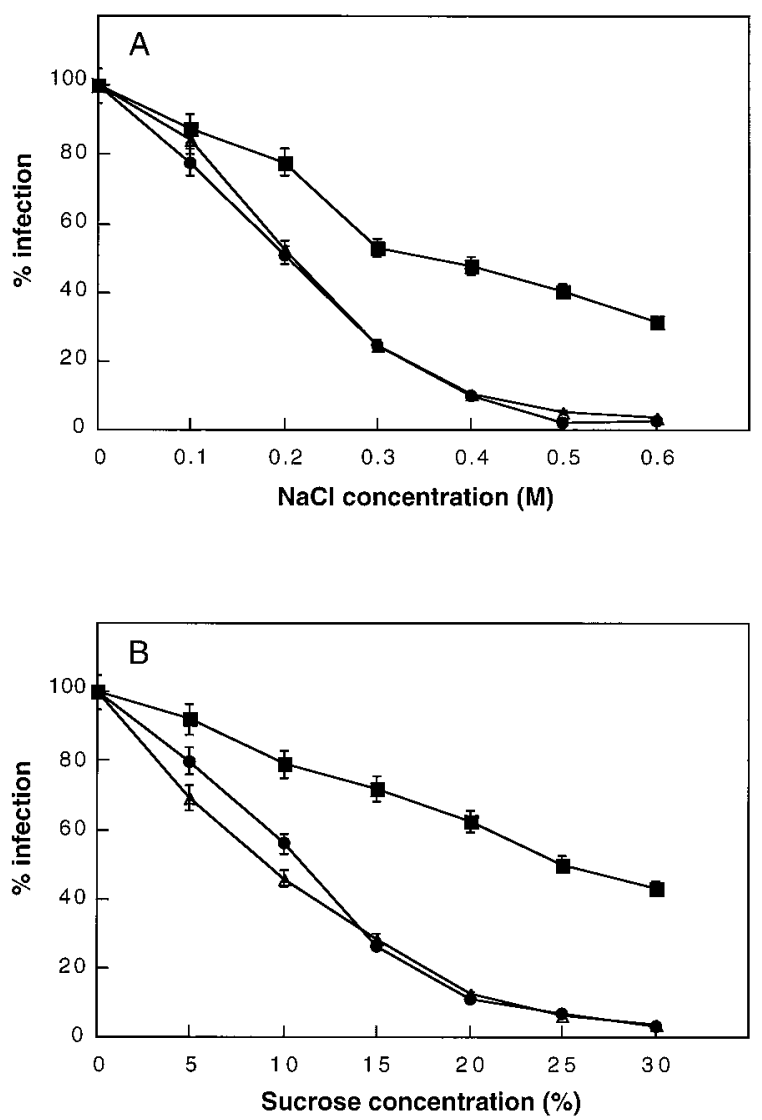

FIG. 3. Effect of osmolarity on the infection of Stx2-converting phages. E. coli $\mathrm{C} 600$ was cultured in $\mathrm{LB}$ broth supplemented with various concentrations of $\mathrm{NaCl}(\mathrm{A})$ or sucrose $(\mathrm{B})$, and the bacterial culture $\left(5 \times 10^{7}\right.$ cells) was incubated with $5 \times 10^{3}$ PFU of Stx2 2 -I $(\bullet)$, Stx2 9 -II $(\mathbf{\square})$, or $933 \mathrm{~W}(\mathbf{\Delta})$ in a volume of $0.2 \mathrm{ml}$. After incubation at $37^{\circ} \mathrm{C}$ for $60 \mathrm{~min}$, the samples were plated and incubated at $37^{\circ} \mathrm{C}$ for $18 \mathrm{~h}$ to determine phage infectivity. The data shown are the means of triplicate experiments.

restored upon introduction of both plasmid pMAW320 (a cloned fadL gene in pSU18) and pMAW301 (a cloned lamB gene in pUC119). Introduction of pMAW320 (a cloned fadL gene in pSU18) alone into MW78 ( $\mathrm{fadL}$ lamB) restored the sensitivity to Stx2 $\Phi-I$ and $933 \mathrm{~W}$ but not Stx2Ф-II (Table 4), while the introduction of pMAW301 (a cloned lamB gene in pUC119) into MW78 ( fadL lamB) only partly restored the sensitivity to Stx2Ф-II.

Contribution of FadL and LamB protein to Stx2-converting phage infection. Table 4 shows that a fadL mutation had a significant effect on the efficiency of infection of Stx2-converting phages and that a $\operatorname{lamB}$ mutation affected Stx $2 \Phi-I I$ infection of $E$. coli. This was further demonstrated by using a phage neutralization experiment. Outer membrane fractions prepared from each of the strains C600, MW72 (fadL), MW47 $(\operatorname{lamB})$, and MW78 ( $\mathrm{fadL} \operatorname{lamB})$ were incubated with Stx2converting phage at $37^{\circ} \mathrm{C}$ for $60 \mathrm{~min}$, the phages were plated with $\mathrm{C} 600$, and the ineffective phage numbers were assayed as described in Materials and Methods. The outer membrane fraction from C600 efficiently inactivated the infectivity of Stx2Ф-I, Stx2Ф-II, and 933W (Fig. 4, column A). However, the outer membrane fraction from strain MW72 ( $\mathrm{fadL}$ ) was unable to inactivate Stx2Ф-I and 933W (97 and 98\% surviving phages, respectively) (column $\mathrm{B}$ ). Under the same conditions, the outer membrane fraction from MW47 ( $\operatorname{lam} B)$ could inactivate
TABLE 4. Average plating efficiencies of Stx2-converting phage

\begin{tabular}{|c|c|c|c|c|}
\hline \multirow{2}{*}{ Strain } & \multirow{2}{*}{$\begin{array}{l}\text { Genotype and } \\
\text { characteristics }\end{array}$} & \multicolumn{3}{|c|}{ Phage titer } \\
\hline & & Stx2Ф-I & Stx $2 \Phi-I I$ & $933 \mathrm{~W}$ \\
\hline C600 & Reference & $2.4 \times 10^{7}$ & $2.6 \times 10^{7}$ & $3.9 \times 10^{7}$ \\
\hline MW47 & $\operatorname{lamB}$ & $2.2 \times 10^{7}$ & $3.1 \times 10^{3}$ & $3.2 \times 10^{7}$ \\
\hline MW47(pMAW301) & $\operatorname{lam} B^{+}$ & $2.3 \times 10^{7}$ & $2.8 \times 10^{7}$ & $2.9 \times 10^{7}$ \\
\hline RAM191 & отрC & $1.9 \times 10^{7}$ & $1.9 \times 10^{7}$ & $2.8 \times 10^{7}$ \\
\hline RK4786 & ompF & $2.0 \times 10^{7}$ & $2.2 \times 10^{7}$ & $3.4 \times 10^{7}$ \\
\hline MW72 & $f a d L$ & $\mathrm{ND}^{a}$ & $7.7 \times 10^{3}$ & ND \\
\hline MW72(pMAW302) & $\mathrm{fadL}^{+}$ & $2.7 \times 10^{7}$ & $2.6 \times 10^{7}$ & $2.9 \times 10^{7}$ \\
\hline MW78 & fadL lamB & ND & ND & ND \\
\hline MW78(pMAW320) & $\mathrm{fadL} L^{+} \operatorname{lam} B$ & $1.2 \times 10^{7}$ & $9.9 \times 10^{3}$ & $1.5 \times 10^{7}$ \\
\hline MW78(pMAW301) & fadL $\operatorname{lamB}^{+}$ & ND & $1.2 \times 10^{4}$ & ND \\
\hline $\begin{array}{l}\text { MW78(pMAW320, } \\
\text { pMAW301) }\end{array}$ & $\mathrm{fadL}^{+} \operatorname{lamB}^{+}$ & $8.2 \times 10^{7}$ & $9.3 \times 10^{7}$ & $8.4 \times 10^{7}$ \\
\hline
\end{tabular}

${ }^{a} \mathrm{ND}$, not detectable.

Stx2Ф-I and 933W completely (column D). In contrast, the outer membrane fractions from strain MW72 ( $f a d L)$ and MW47 $(\operatorname{lam} B)$ could partially inactivate Stx2Ф-II (59 and 46\% surviving phages, respectively) (column B or D), and the outer membrane fraction from strain MW78 ( fadL lamB) was unable to neutralize the infectivity of all the three phages (column F). Furthermore, upon addition of the His-tagged FadL protein to the phage solutions, the infective capacity of Stx2 $\Phi$-I and $933 \mathrm{~W}$ decreased with increases of the protein concentration. In fact, at a concentration of $20 \mu \mathrm{g} / \mathrm{ml}$, the inhibition of the ineffective capacity of Stx2 $\Phi-\mathrm{I}$ and $933 \mathrm{~W}$ to C600 reached the maximum point, at which $75 \%$ of the original phage infectivity (zero) was blocked by the His-tagged FadL protein (Fig. 5A). In contrast, inhibition of the infective capacity of Stx2 $\Phi-I I$ decreased partially upon addition of the His-tagged FadL or LamB protein (56\% for His-tagged FadL and $47 \%$ for LamB) (Fig. 5). These results strongly suggest that the receptor for

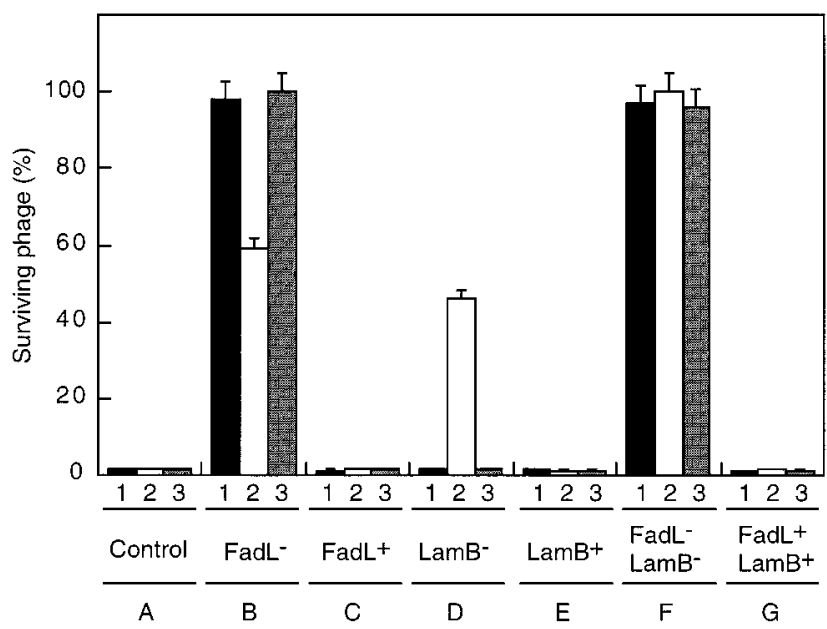

FIG. 4. Neutralization of Stx2-converting phages by the outer membrane fractions of various bacterial strains. The insoluble fraction obtained after extraction of whole-cell envelopes with $2 \%$ Triton X-100 and $5 \mathrm{mM} \mathrm{MgCl}_{2}$ is the outer membrane fraction. The outer membrane fraction $(100 \mu \mathrm{g} / \mathrm{ml})$ was incubated with $5 \times 10^{3}$ PFU of Stx2 $\Phi$-I (lanes 1), Stx $2 \Phi$-II (lanes 2), and 933W (lanes 3 ) in a volume of $1 \mathrm{ml}$. After incubation at $37^{\circ} \mathrm{C}$ for $60 \mathrm{~min}, 0.2-\mathrm{ml}$ samples were plated with strain C600 to determine the plaque number of surviving phage. The data shown are the means of triplicate experiments. The strains from which the outer membrane fraction was extracted are as follows: A, C600; B, MW72; C, MW72(pMAW302); D, MW47; E, MW47(pMAW301); F, MW78; G, MW78 (pMAW320, pMAW301). 

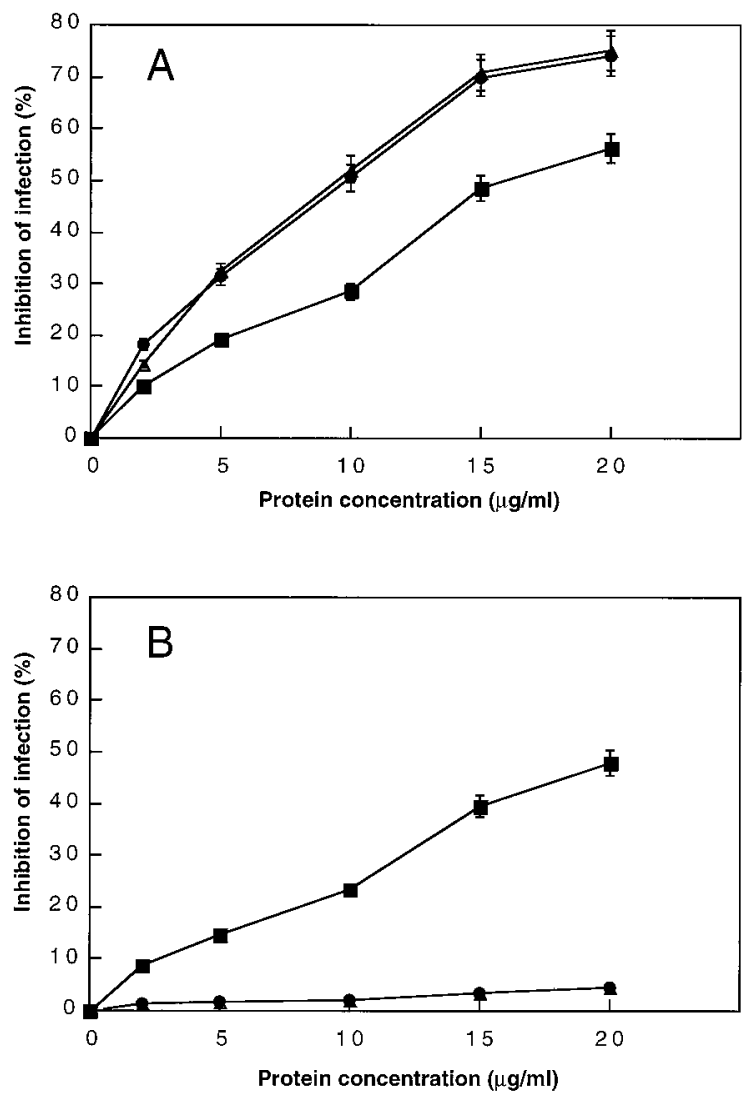

FIG. 5. Effect of FadL and LamB on infection of E. coli C600 by Stx2converting phages. Stx $2 \Phi-\mathrm{I}(\bullet)$, Stx $2 \Phi-\mathrm{II}(\boldsymbol{\square})$, and $933 \mathrm{~W}(\boldsymbol{\Delta})\left(5 \times 10^{3} \mathrm{PFU}\right)$ were treated with various concentrations of purified $\mathrm{His}_{6}$-tagged FadL (A) or LamB (B) fusion protein in a volume of $1 \mathrm{ml}$. After incubation at $37^{\circ} \mathrm{C}$ for $60 \mathrm{~min}$, 0.2-ml samples were plated with strain C600 to determine the inhibition of phage infection. The data shown are the means of triplicate experiments.

Stx2Ф-I and 933W was the FadL protein and that for Stx2Ф-II consisted of the both FadL and LamB proteins.

\section{DISCUSSION}

Stx1 and Stx2 are the major virulence factors of STEC and are responsible for the symptoms of bloody diarrhea and HUS. The stx 1 and stx 2 genes so far reported have been found as a part of the lambdoid phage genome, thus allowing the toxin genes to spread easily from one E. coli strain to another. It is therefore important to investigate the distribution of Stx-converting phages in STEC strains associated with outbreaks and to understand their infective properties. In this study, we attempted to isolate Stx-converting phages from five STEC strains that were associated with different outbreaks in Japan in 1996 and succeeded in identifying two different types of Stx2-converting phages, designated Stx2Ф-I and Stx2Ф-II.

Detailed characterization of Stx $2 \Phi-I$ and Stx2 $\Phi$-II showed that the stx2 gene of Stx2Ф-I and Stx2Ф-II was identical to that of $933 \mathrm{~W}$, the sole known Stx2-converting phage (34). Furthermore, it was found that Stx $2 \Phi-\mathrm{I}$ is closely related to $933 \mathrm{~W}$ but not to Stx2Ф-II and that Stx2Ф-II is a novel Stx2-converting phage. Our conclusion was drawn from the following results. The plaques of Stx2 $\Phi$-II developed in C600 were significantly smaller than those of Stx2Ф-I, for which the morphology of plaques resembled that of $933 \mathrm{~W}$. Although the full length of the Stx2 $\Phi$-I genome was similar to that of $933 \mathrm{~W}(7,34,45,49)$, it was approximately $3 \mathrm{~kb}$ smaller than that of Stx2 $\Phi$-II (Fig. 2). The phage infection immunity displayed by Stx2Ф-I, Stx2 $\Phi-I I$, and $933 \mathrm{~W}$ revealed that Stx $2 \Phi-\mathrm{I}$ and $933 \mathrm{~W}$ belong to the same immunity group but that Stx2 $\Phi$-II does not. In support of this view, the effect of changes in the osmolarity of the medium on the infection of C600 by Stx2 $\Phi-\mathrm{I}$ or $933 \mathrm{~W}$ was different from that on infection by Stx2Ф-II (Fig. 5). The differences would result from different expression of the outer membrane proteins used as the phage receptors on the host E. coli $\mathrm{K}-12$ in media with different osmolarities. In fact, the infectivity of Stx2 $\Phi-I$ and $933 \mathrm{~W}$ was strongly dependent upon the FadL protein expressed on C600, while that of Stx2 $\Phi$-II was dependent on both LamB and FadL expression (Table 4). The different proteins involved in the phage infection of $E$. coli were also confirmed by performing phage neutralization experiments with outer membrane fractions of the isogenic $E$. coli strains with defined $\operatorname{lam} B, \operatorname{fad} L$, or $\operatorname{lam} B$ fadL mutations or by using the purified $\mathrm{His}_{6}$-tagged FadL or LamB protein. These data clearly indicate that Stx2 $\Phi$-I and Stx2Ф-II are not identical to each other but have diverged considerably.

Most double-stranded-DNA-tailed bacteriophages of enteric bacteria have been assigned to one of several phage groups or so-called quasi-species, where phages of the same group are considered to have a common gene pool. Common to the tailed phages is a highly structured genome composed of a specifically ordered set of genetic modules (43). The order of the functional genetic modules is conserved among members of a phage group and sometimes also between unrelated phage groups. A recent study of 12 lambdoid phage genomes illustrated that an individual phage genome can be considered to be a particular combination of "alleles" of genetic modules that are available in the gene pool of that phage group (17). Two recently published studies documented a surprisingly promiscuous exchange of gene segments across phage group boundaries $(12,42)$. In this context, it is tempting to speculate that the different requirements of the outer membrane of E. coli $\mathrm{K}-12$, as mentioned above, would be reflected by different compositions of the tail proteins, since the FadL and LamB proteins have been shown to be the receptors for the T2 and $\lambda$ phages, respectively $(29,40)$. Taking the above notion into account, we assumed that recombination of tail fiber gene segments between the Stx2-converting phages and other phages such as T2 or $\lambda$ phages could have occurred. Rearrangement of the tail fibers of Stx2-converting phages with those of some other phages through exchange of part of the tail genes would be beneficial for enhancing the phage host range, resulting in the emergence of various STEC strains.

In this study, we observed that secretion of Stx2 into the culture supernatant from C600 lysogenized with Stx2Ф-I or Stx2Ф-II was greatly diminished compared with that from the STEC strains Okayama O-29 and Morioka V526, as determined by ELISA with anti-Stx 2 antibody (Table 2). This is reminiscent of our previous report that secretion of Stx 2 from C600 carrying a cloned stx 2 gene was greatly reduced compared with that from the parental STEC strain (60). Thus, these data suggest that the functions required for the secretion of Stx 2 are not encoded by the phage itself but, rather, may be encoded by the chromosome of STEC. Although the precise secretion system still remains to be elucidated, it is possible that the genes required for the secretion of Stx 2 protein are located on some chromosomal region unique to the STEC strains. Indeed, the recent whole genomic sequencing of some of the STEC strains has indicated that STEC strains possess at least $1.5 \mathrm{Mb}$ of additional DNA sequence compared to $E$. coli K-12 (13a). Alternatively, the increased secretion of Stx 2 from the STEC strains examined in this study may have resulted 
from the additional copy of stx2 genes, as indicated by Schmitt et al. (46), who showed that STEC strains had two copies of the stx2 gene. Indeed, the STEC strains examined in this study also possess two copies of the stx2 gene, one in Stx2Ф-I or Stx2Ф-II and the other located somewhere in the chromosome (data not shown). In any case, we must await the results of further studies to elucidate the precise secretion system involved in Stx2 secretion from STEC strains.

STEC strains associated with bloody diarrhea and HUS can be detected by different methods. The methods that have been used to subtype E. coli $\mathrm{O} 157: \mathrm{H} 7$ strains include Stx genotype determination (31), plasmid profile analysis $(38,55)$, multilocus enzyme electrophoresis (56), antimicrobial susceptibility (50), bacteriophage typing (1), random amplified polymorphic DNA fingerprinting (51), and genomic DNA restriction fragment length polymorphism analysis (39). In addition, pulsedfield gel electrophoresis has recently been successfully used in the determination of the molecular epidemiology of STEC strains (2). We have also developed a detection method for STEC strains that involves a sensitive bead ELISA and PCR with common and specific primers for various Stxs (57). The detailed information on Stx $2 \Phi$-I or Stx $2 \Phi$-II provided by this study would be useful for epidemiological studies in the future. By applying the facts to the epidemiological classification of STEC strains, we can successfully identify the origin of each outbreak by tracing the route of the food contamination. In this sense, the development of a monitoring system for the distribution of Stx-converting phages in members of the Enterobacteriaceae should be an important step. In this context, we are currently sequencing the whole genomes of Stx2 $\Phi-I$ and Stx2Ф-II and seeking phage-specific sequences to develop diagnostic DNA probes.

\section{ACKNOWLEDGMENTS}

We thank G. Balakrish Nair for critical reading of the manuscript, Tae Takeda for providing STEC strains, and Hideo Hayashi for valuable discussion.

M. Watarai is the recipient of a Research Fellowship of the Japan Society for the Promotion of Science for Young Scientists. This study was supported by the Organization for Pharmaceutical Safety and Research (OPSR).

\section{REFERENCES}

1. Ahmed, R., C. Bopp, A. Borczyk, and S. Kasatiya. 1987. Phage-typing scheme for Escherichia coli serotype O157:H7. J. Infect. Dis. 155:806-809.

2. Barrett, T. J., H. Lior, J. H. Green, R. Khaharia, J. G. Wellis, B. P. Bell, K. D. Greene, J. Lewis, and P. M. Griffin. 1994. Laboratory investigation of a multistate food-borne outbreak of Escherichia coli $\mathrm{O} 157: \mathrm{H} 7$ by using pulsed-field gel electrophoresis and phage typing. J. Clin. Microbiol. 32: 1013-1017.

3. Bartolomé, B., Y. Jubete, E. Martinez, and F. de la Cruz. 1991. Construction and properties of a family of pACYC184-derived cloning vectors compatible with pBR322 and its derivatives. Gene 102:75-78.

4. Black, P. N. 1991. Primary sequence of the Escherichia coli fadL gene encoding an outer membrane protein required for long-chain fatty acid transport. J. Bacteriol. 173:435-442.

5. Clement, J. M., and M. Hofnung. 1981. Gene sequence of the lambda receptor, an outer membrane protein of E. coli K12. Cell 27:507-514.

6. Dagert, M., and S. D. Erlich. 1979. Prolonged incubation in calcium chloride improves the competence of Escherichia coli. Gene 6:23-28.

7. Datz, M., C. Janetzki-Mittmann, S. Franke, F. Gunzer, H. Schmidt, and H. Karch. 1996. Analysis of the enterohemorrhagic Escherichia coli O157:H7 DNA region containing lambdoid phage gene $p$ and Shiga-like toxin structural genes. Appl. Environ. Microbiol. 62:791-797.

8. Davis, L. G., M. D. Dibner, and J. F. Battey. 1986. Basic methods in molecular biology. Elsevier Science Publishing Co., New York, N.Y.

9. Gannon, V. P. J., C. Teerling, S. A. Masrei, and C. L. Gyles. 1990. Molecular cloning and nucleotide sequence of another variant of the Escherichia coli Shiga-like toxin II family. J. Gen. Microbiol. 136:1125-1135.

10. Griffin, P. M., and R. V. Tauxe. 1991. The epidemiology of infections caused by Escherichia coli O157:H7, other enterohemorrhagic E. coli, and the associated hemolytic uremic syndrome. Epidemiol. Rev. 13:60-98.
11. Gyles, C. L., S. A. DeGrandis, C. MacKenzie, and J. L. Brunton. 1988. Cloning and nucleotide sequence analysis of the genes determining verocytotoxin production in a porcine edema disease isolate of Escherichia coli. Microb. Pathog. 5:419-426.

12. Haggard-Ljungquist, E., C. Halling, and R. Calendar. 1992. DNA sequences of the tail fiber genes of bacteriophage P2: evidence for horizontal transfer of tail fiber genes among unrelated bacteriophages. J. Bacteriol. 174:14621477.

13. Hantke, K. 1978. Major outer membrane proteins of E. coli K12 serve as receptors for the phages T2 (protein 1) and 434 (protein 1). Mol. Gen. Genet. 164:131-135.

13a.Hayashi, H., and H. Shinagawa. Personal communication.

14. Head, S. C., M. A. Karmali, M. E. Roscoe, M. Petric, N. A. Strockbine, and I. K. Wachsmuth. 1988. Serological differences between verocytotoxin 2 and Shiga-like toxin II. Lancet ii:571. (Letter.)

15. Heller, K., B. J. Mann, and R. J. Kadner. 1985. Cloning and expression of the gene for the vitamin $\mathrm{B}_{12}$ receptor protein in the outer membrane of Escherichia coli. J. Bacteriol. 161:896-903.

16. Henning, U., and K. Jahn. 1979. Two-component nature of bacteriophage T4 receptor activity in Escherichia coli K-12. J. Bacteriol. 137:664-666.

17. Highton, P. J., Y. Chang, and R. J. Myers. 1990. Evidence for the exchange of segments between genomes during the evolution of lambdoid bacteriophages. Mol. Microbiol. 4:1329-1340.

18. Huang, A., S. De Grandis, J. Friesen, M. Karmali, M. Petric, R. Congi, and J. L. Brunton. 1986. Cloning and expression of the genes specifying Shigalike toxin production in Escherichia coli H19. J. Bacteriol. 166:375-379.

19. Huang, A., J. Friesen, and J. L. Brunton. 1987. Characterization of a bacteriophage that carries the genes for production of Shiga-like toxin 1 in Escherichia coli. J. Bacteriol. 169:4308-4312.

20. Imagawa, M., S. Yoshitake, E. Ishikawa, Y. Niitsu, I. Urushizaki, R. Kanazawa, S. Tachibana, N. Nakazawa, and H. Ogawa. 1982. Development of a highly sensitive sandwich enzyme immunoassay for human ferritin using affinity-purified anti-ferritin labelled with beta-D-galactosidase from Escherichia coli. Clin. Chim. Acta 121:277-289.

21. Ito, H., A. Terai, H. Kurazono, Y. Takeda, and M. Nishibuchi. 1990. Cloning and nucleotide sequencing of Vero toxin 2 variant genes from the Escherichia coli $\mathrm{O} 91: \mathrm{H} 21$ isolated from a patient with the hemolytic uremic syndrome. Microb. Pathog. 8:47-60.

22. Jackson, M. P., R. J. Neill, A. D. O'Brien, R. K. Holmes, and J. W. Newland. 1987. Nucleotide sequence analysis and comparison of the structural genes for Shiga-like toxin I and Shiga-like toxin II encoded by bacteriophages from Escherichia coli 933. FEMS Microbiol. Lett. 44:109-114.

23. Kurazono, H., C. Sasakawa, M. Yoshikawa, and Y. Takeda. 1987. Cloning of a Vero toxin (VT1, Shiga-like toxin I) gene from a VT1-converting phage isolated from Escherichia coli O157:H7. FEMS Microbiol. Lett. 48:23-26.

24. Levine, M. M. 1987. Escherichia coli that cause diarrhea: enterotoxigenic, enteropathogenic, enteroinvasive, enterohemorrhagic, and enteroadherent. J. Infect. Dis. 155:377-389.

25. MacLeod, D. L., and C. L. Gyles. 1990. Purification and characterization of an Escherichia coli Shiga-like toxin II variant. Infect. Immun. 58:1232-1239.

26. Manning, P. A., L. Beutin, and M. Achtman. 1980. Outer membrane of Escherichia coli: properties of the F sex factor traT protein which is involved in surface exculusion. J. Bacteriol. 142:285-294.

27. Miller, J. H. 1972. Experiments in molecular genetics. Cold Spring Harbor Laboratory, Cold Spring Harbor, N.Y.

28. Misra, R., and S. A. Benson. 1988. Isolation and characterization of OmpC porin mutants with altered pore properties. J. Bacteriol. 170:528-533.

29. Morona, R., and U. Henning. 1986. New locus (ttr) in Escherichia coli K-12 affecting sensitivity to bacteriophage T2 and growth on oleate as the sole carbon source. J. Bacteriol. 168:534-540.

30. Mutoh, N., H. Furukawa, and S. Mizushima. 1978. Role of lipopolysaccharide and outer membrane protein of Escherichia coli K-12 in the receptor activity for bacteriophage T4. J. Bacteriol. 136:693-699.

31. Newland, J. W., and R. J. Neill. 1988. DNA probes for Shiga-like toxins I and II and for toxin-converting phages. J. Clin. Microbiol. 26:1292-1297.

32. Noda, M., T. Yutsudo, N. Nakabayashi, T. Hirayama, and Y. Takeda. 1987. Purification and some properties of Shiga-like toxin from Escherichia coli O157:H7 that is immunologically identical to Shiga toxin. Microb. Pathog. 2: 339-349.

33. O'Brien, A. D., J. W. Newland, S. F. Miller, R. K. Holmes, H. W. Smith, and S. B. Formal. 1984. Shiga-like toxin-cinverting phages from Escherichia coli strains that cause hemorrhagic colitis or infantile diarrhea. Science 226:694696.

34. O'Brien, A. D., L. R. M. Marques, C. F. Kerry, J. W. Newland, and R. K. Holmes. 1989. Shiga-like toxin converting phage of enterohemorrhagic Escherichia coli strain 933. Microb. Pathog. 6:381-390.

35 O'Brien, A. D., V. L. Tesh, A. Donohue-Rolfe, M. P. Jackson, S. Olsnes, K. Sandvig, A. A. Lindberg, and G. T. Keusch. 1992. Shiga toxin: biochemistry, genetics, mode of action, and role in pathogenesis. Curr. Top. Microbiol. Immunol. 180:65-94.

36. Oku, Y., Y. Uesaka, T. Hirayama, and Y. Takeda. 1988. Development of a 
highly sensitive bead-ELISA to detect bacterial protein toxins. Microbiol. Immunol. 32:807-816.

37. Oliver, D. B. 1985. Identification of five new essential genes involved in the synthesis of a secreted protein in Escherichia coli. J. Bacteriol. 161:285-291.

38. Ostroff, S. M., P. I. Tarr, M. A. Neill, J. H. Lewins, N. Hargrett-Bean, and J. M. Kobayashi. 1989. Toxin genotypes and plasmid profiles as determinants of systemic sequelae in Escherichia coli O157:H7 infection. J. Infect. Dis. 160:994-998.

39. Paros, M., P. I. Tarr, H. Kim, T. E. Besser, and D. D. Hancock. 1993. A comparison of human and bovine Escherichia coli $\mathrm{O} 157: \mathrm{H} 7$ isolates by toxin genotype, plasmid profile, and bacteriophage lambda-restriction fragment length polymorphism profile. J. Infect. Dis. 168:1300-1303.

40. Randall-Hazelbauer, L., and M. Schwartz. 1973. Isolation of the bacteriophage lambda receptor from Escherichia coli. J. Bacteriol. 116:1436-1446.

41. Sambrook, J., E. F. Fritsch, and T. Maniatis. 1989. Molecular cloning: a laboratory manual, 2nd ed. Cold Spring Harbor Laboratory, Cold Spring Harbor, N.Y.

42. Sandmeier, H., S. Iida, and W. Arber. 1992. DNA inversion regions Min of plasmid p15B and Cin of bacteriophage P1: evolution of bacteriophage tail fiber genes. J. Bacteriol. 174:3936-3944.

43. Sandmeier, H. 1994. Acquisition and rearrangement of sequence motifs in the evolution of bacteriophage tail fibres. Mol. Microbiol. 12:343-350.

44. Sanger, F., S. Nicklen, and A. R. Coulson. 1977. DNA sequencing with chain-terminating inhibitors. Proc. Natl. Acad. Sci. USA 74:5463-5467.

45. Schmidt, H., J. Scheef, C. Janetzki-Mittmann, M. Datz, and H. Karch. 1997. An ileX tRNA gene is located close to the Shiga toxin II operon in enterohemorrhagic Escherichia coli O157 and non-O157 strains. FEMS Microbiol. Lett. 149:39-44.

46. Schmitt, C. K., M. L. McKee, and A. D. O'Brien. 1991. Two copies of Shiga-like toxin II-related genes common in enterohemorrhagic Escherichia coli strains are responsible for the antigenic heterogeneity of the $0157: \mathrm{H}^{-}$ strain E32511. Infect. Immun. 59:1065-1073.

47. Scotland, S. M., H. R. Smith, and B. Rowe. 1985. Two distinct toxins active on Vero cells from Escherichia coli O157. Lancet ii:885-886.

48. Smith, H. W., P. Green, and Z. Parsell. 1983. Vero cell toxins in Escherichio coli and related bacteria: transfer by phage and conjugation and toxic action in laboratory animals, chickens, and pigs. J. Gen. Microbiol. 129:3121-3137.

49. Strockbine, N. A., L. R. M. Marques, J. W. Newland, H. W. Smith, R. K Holmes, and A. D. O'Brien. 1986. Two toxin-converting phages from Esch- erichia coli $\mathrm{O} 157: \mathrm{H} 7$ strain 933 encode antigenically distinct toxins with similar biologic activities. Infect. Immun. 53:135-140.

50. Swerdlow, D. L., B. A. Woodruff, R. C. Brady, P. M. Griffin, S. Tippen, H. D. Donnell, E. Geldreich, B. J. Payne, A. Meyer, J. G. Wells, K. D. Greene, M. Bright, N. H. Bean, and P. A. Blake. 1992. A waterborne outbreak in Missouri of Escherichia coli O157:H7 associated with bloody diarrhea and death. Ann. Intern. Med. 117:812-818.

51. Wang, G., T. S. Whittam, C. M. Berg, and D. E. Berg. 1993. RAPD (arbitrary primer) PCR is more sensitive than multilocus enzyme electrophoresis for distinguishing related bacterial strains. Nucleic Acids Res. 2157:5930-5933.

52. Watanabe, H., A. Wada, and Y. Inagaki. 1996. Outbreaks of enterohaemorrhagic Escherichia coli $\mathrm{O} 157: \mathrm{H} 7$ infection by two different genotype strains in Japan, 1996. Lancet 348:831-832.

53. Watarai, M., T. Tobe, M. Yoshikawa, and C. Sasakawa. 1995. Contact of Shigella with host cells triggers release of Ipa invasins and is an essential function of invasiveness. EMBO J. 14:2461-2470.

54. Weinstein, D. L., M. P. Jackson, J. E. Samuel, R. K. Holmes, and A. D. O'Brien. 1988. Cloning and sequencing of a Shiga-like toxin II variant from an Escherichia coli strain responsible for edema disease of swine. J. Bacteriol. 170:4223-4230.

55. Wells, J. G., B. R. Davis, I. K. Wachsmuth, L. W. Riley, R. S. Remis, R. Sokolow, and G. K. Morris. 1983. Laboratory investigation of hemorrhagic colitis associated with a rare Escherichia coli serotype. J. Clin. Microbiol. 18: $512-520$.

56. Whittam, T. S., I. K. Wachsmuth, and R. A. Wilson. 1988. Genetic evidence of clonal descent of Escherichia coli O157:H7 associated with hemorrhagic colitis and hemolytic uremic syndrome. J. Infect. Dis. 157:1124-1133.

57. Yamasaki, S., S. Lin, H. Shirai, A. Terai, Y. Oku, H. Ito, M. Ohmura, T. Karasawa, T. Tsukamoto, H. Kurazono, and Y. Takeda. 1996. Typing of verotoxins by DNA hybridization with poly- and oligonucleotide probes, a bead-enzyme-linked immunosorbent assay, and polymerase chain reaction. Microbiol. Immunol. 40:345-352.

58. Yutsudo, T., N. Nakabayashi, T. Hirayama, and Y. Takeda. 1987. Purification and some properties of a Vero toxin from Escherichia coli $\mathrm{O} 157: \mathrm{H} 7$ that is immunologically unrelated to Shiga toxin. Microb. Pathog. 3:21-30.

59. Yutsudo, T., H. Kurazono, C. Sasakawa, M. Yoshikawa, and Y. Takeda. 1987. Cloning of a Vero toxin (VT2) gene from a VT2-converting phage isolated from Escherichia coli O157:H7. FEMS Microbiol. Lett. 48:273-276.

Editor: J. T. Barbieri 